\title{
Evaluation of microscopic protocols for somatic cell counts in milk of dairy sheep
}

\author{
Avaliação de protocolos do método microscópico para contagem de células \\ somáticas no leite de ovelhas leiteiras
}

\author{
Cristiane Rosa Moraes ${ }^{1}$, Tatiana Regina Vieira², Andrea Troller Pinto², Verônica Schmidt²*
}

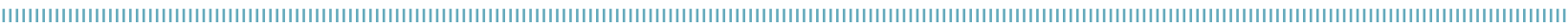

\begin{abstract}
The somatic cell count (SCC) is a diagnostic tool that indicates the mammary gland health and can be determined by the counting of cells in the microscope. There are discussions regarding appropriate staining method to the ewes' milk. The present study aimed to identify a methodology of microscopic SCC proper to the milk of the ovine species. Therefore, glass slides for smear were manufactured with $10 \mu \mathrm{L}$ of ewe's milk in $1 \mathrm{~cm}^{2}$, and the fixers xylol and Carnoy's solution were tested, as well as and May-Grünwald, Broadhurst-Paley, Wrigth and Panoptic stainings. Carnoy's solution was elected, because it allowed a better fixation of the dairy film to the microscope slides, and Broadhurst-Paley staining, due to its good coloration and visualization of cells, as well as the differentiation of cytoplasmic corpuscles in ewe's milk. Broadhurst-Paley coloration is a tool applicable to the somatic cell count in ovine specie's milk.
\end{abstract}

KEYWORDS: somatic cell count; Broadhurst-Paley staining; Lacaune.
RESUMO: A contagem de células somáticas é uma ferramenta de diagnóstico indicativa da saúde da glândula mamária e pode ser determinada em microscópio. Sobre ela, existem discussóes quanto à coloração adequada ao leite de ovelhas. O presente estudo objetivou identificar uma metodologia de preparação de lâminas para a contagem microscópica de células somáticas do leite da espécie ovina. Para tanto, confeccionaram-se lâminas de esfregaços de $10 \mu \mathrm{L}$ de leite de ovelha em $1 \mathrm{~cm}^{2}$, testaram-se os fixadores de xilol e solução de Carnoy e as coloraçóes de May-Grünwald, Broadhurst-Paley, Wrigth e Panótico. Elegeram-se a solução de Carnoy, pois esta permitiu melhor fixação do filme lácteo às lâminas de microscopia, e o corante Broadhurst-Paley, que propiciou boa coloração e visualização das células, bem como a diferenciação dos corpúsculos citoplasmáticos presentes no leite ovino. A coloração é uma ferramenta aplicável à contagem de células somáticas no leite da espécie ovina.

PALAVRAS-CHAVE: contagem de células somáticas; coloração Broadhurst-Paley; Lacaune. 
Mastitis is one of the major problems related to milk production, because it causes economic losses, resulting from the reduction in volume of milk produced, and of the costs of treatment. Sometimes there is even animal loss. Although well known in bovine species, studies about this disease in ovine species are scarce (BAGLITZ et al., 2008).

The diagnosis of subclinical mastitis can be performed through the somatic cell count (SCC), i.e., the examination of structures of the organism defense before inflammation or infection and composed by immune system cells (somatic cells) and epithelial cells (SUMMER et al., 2012). As an indicator of the mammary gland health and the milk quality, the SCC is quite studied in bovine species (VIANA et al., 2010). However, the ewe's milk is an apocrine secretion and presents cytoplasmic particles, which have similar size and shape to the leucocytes, and that can generate some confusion in automated methods of cell count (MADUREIRA et al., 2010). Therefore, the count of cells by direct microscopy is indicated for the ovine species. However, there is disagreement regarding the staining procedures suitable for this species (GOMES et al., 2008), and the protocols of specific staining for DNA are the ones indicated.

Considering the laborious processes for specific staining for DNA, as the color with methyl green and pyronin $\mathrm{Y}$, as well as its high carcinogenic potential (BAGLITZ et al., 2013), the SCC by non-specific staining for DNA can be an applicable tool for the diagnosis of mastitis in sheep (BERRY et al., 2010; GOMES et al., 2008). In this perspective, the objective of this study was to identify a methodology of fixation and staining for SCC by optical microscopy in ewes' milk.

The investigation was carried out in a commercial herd for milk production, with dairy sheep in different phases and number of lactations, located in the serrana region of Rio Grande do Sul state, Brazil. Samples were collected from individualized milk by teat, in sterile flasks, and identified, after asepsis with $70 \%$ alcohol and disregarding the first three jets. The samples were packed in isothermal boxes with ice packs for later processing of different methods of fixation and staining.

For the slides preparation, an aliquot of $10 \mu \mathrm{L}$ of sample was deposited on the glass slide, supported on mold with an area of $1 \mathrm{~cm}^{2}$ (SCHALM et al., 1971). The slides were kept at room temperature for 24 hours, for drying. They were subsequently fixed and stained, creating six different combinations:

- DAP1: xylol and May-Grünwald-Giemsa;

- DAP2: xylol and Broadhurst-Paley;

- DAP3: xylol and Wright;

- DAP4: xylol and Panótico ;

- DAP5: Carnoy and May-Grünwald-Giemsa;

- DAP6: Carnoy and Broadhurst-Paley.

For each combination, 48 slides were prepared.
In the first procedure for the milk film fixation, the sample was exposed to heat in a Bunsen burner and steeped in xylene for 10 minutes, for the removal of fat, and washed with distilled water buffered with $\mathrm{pH}$ 7.2. Hereinafter, the slide was submerged in ethyl alcohol for 20 minutes and washed with distilled buffered water, at $\mathrm{pH}$ 7.2.

In the second procedure, the samples were submitted to fixation with Carnoy's solution - composed of ethanol (60\%), formaldehyde (30\%), and acetic acid (10\%) (PUCHTLER et al., 1968) - for ten minutes (GOMES et al., 2010). After, they were hydrated for 1 minute with alcohol $50 \%$ followed by alcohol $30 \%$, for more 1 minute. Then, the slides were washed in distilled water for 1 minute (ARCURI et al., 2004).

Subsequently, the fixed slides were subjected to one of the four staining procedures: May-Grünwald-Giemsa (Laborclin Produtos para Laboratórios, Pinhais, Paraná, Brazil); Wright (Laborclin Produtos para Laboratórios, Pinhais, Paraná, Brazil); and Panótico (Laborclin Produtos para Laboratórios, Pinhais, Paraná, Brazil), according to the manufacturer's instructions, and Broadhurst-Paley as described by SCHALM et al. (1971).

The obtained slides were observed regarding characteristics of smear, fixing and in optical microscope, with immersion oil in $100 \times$ magnification. Microscopy characteristics and cells general appearance were observed.

The characteristics presented in different combinations of fixers/stainings were used to describe the appearance of the obtained slides, and seven groups were created, which effectively describe what was observed in the slides:

1. blurry: loss by limiting the area of $1 \mathrm{~cm}^{2}$;

2. dirty field: many artifacts in the slide;

3. crackled: fragmented milk film;

4. little stained: little impregnated staining;

5. very stained: very impregnated staining;

6. no fixation: loosened milk film;

7. counted: effectively suitable for SCC.

The characteristics pointed before made the cell count difficult, or even impossible (Fig. 1).

The protocol using xylol as fixative and Broadhurst-Paley staining was the one that presented the greatest diversity of characteristics in the slides (blurry, dirty field and little stained), which made the visualization and cell count difficult and impossible, respectively (Table 1). This is the protocol described by SCHALM et al. (1971) for the determination of SCC in bovine milk, which was also used for the determination of SCC in caprine milk (STEHLING et al., 1988). However, the average fat content of 3.9, 4.5 and $7.2 \%$ in cow, goat and sheep milk, respectively (MENDONÇA et al., 2010), should be considered, because the high fat content of ovine milk can make the reading difficult to be performed. 
In the present study, the fat content of the milk sheep made the fixation of milk aliquots in the slides a challenging step, since in the four protocols in which xylol was used as a fixative in only $0.52 \%$ (1/192 slides) it was possible to perform the SCC.

The rinsing, the last step of the staining, presented itself as a critical point, since the samples, which seemed to be fixed, debonded from the slides and were lost.

In the protocols associated with xylol, in most of the slides loss of the counting area limit the presence of artifacts was observed. The staining of Wright and Panóptico showed no good cell definition, and the milk film was smudged (Table 1). VIANA et al. (2010), using the Panótico staining, observed no changes in cell morphology of bovine milk.
In the studied protocols, the characteristic 7 enabled cell count, because the cells were stained in a satisfactory way and well fixed to the slide, with a well delimited area and, practically, without artifacts that could harm the counting procedure. This characteristic was observed in most of the slides of the model PAD6 (Table 1). Although Carnoy's solution has also been used associated to May-Grünwald-Giemsa coloring (PAD5), in this combination most of the slides showed the formation of artifacts that prevented the cell count.

May-Grünwald-Giemsa and Broadhurst-Paley stainings were efficient. However, Broadhurst-Paley staining presented better visualization and the possibility of a differentiation of cell types. In addition, it presented a better
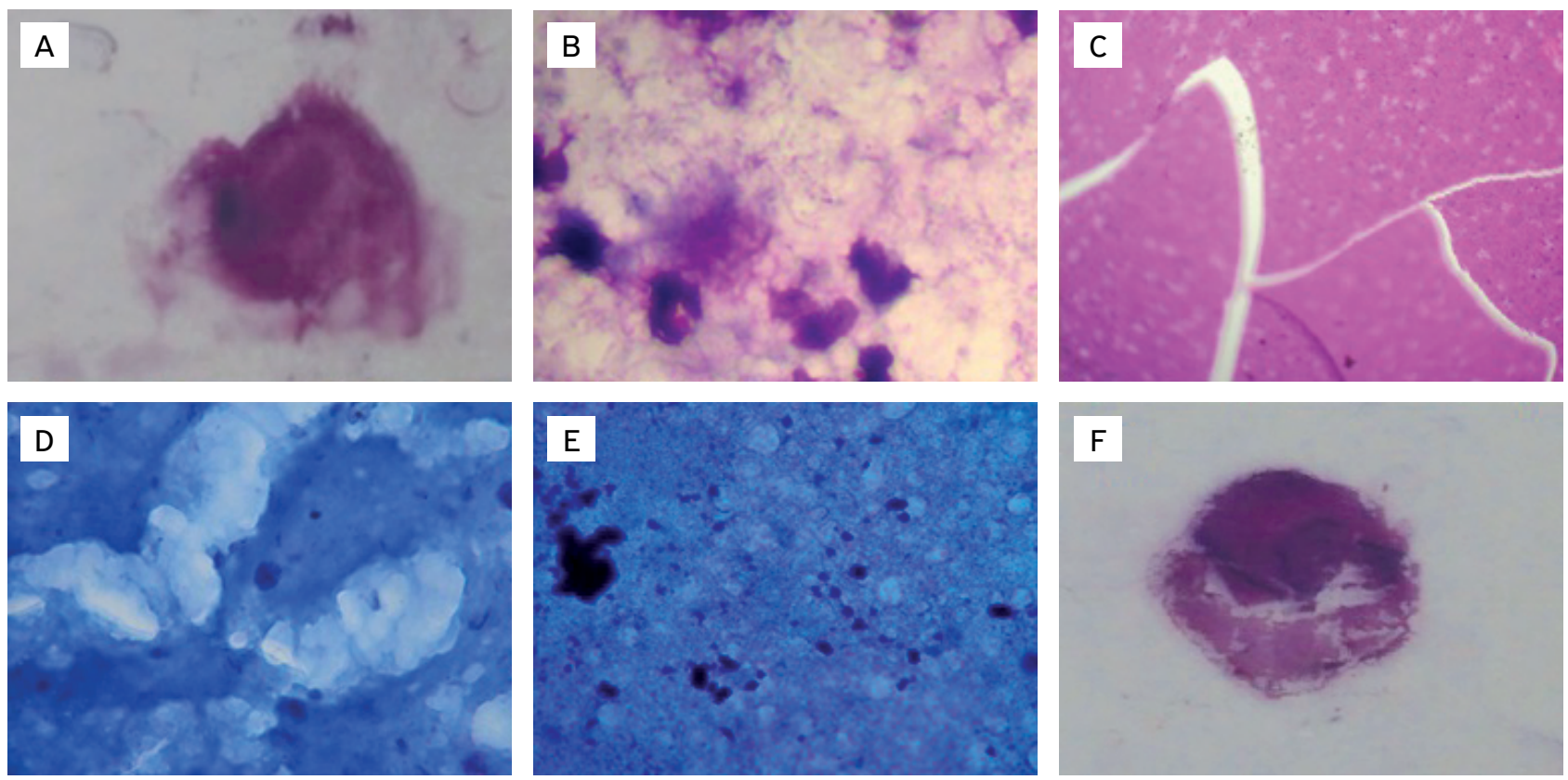

A: Blurred slide; B: dirty field (magnification $100 \times$, immersion in oil); C: crackled (magnification $100 \times$, immersion in oil); D: little stained (magnification $100 \times$, immersion in oil); E: very stained (magnification $100 \times$, immersion in oil); F: milk film without fixation.

Figure 1. Organization of groups of slides for somatic cell counts in ewes' milk, according to the presented characteristics.

Table 1. Methods of fixation and staining of milk film for somatic cell count of ovine milk and the percentage of samples likely to count, according to the slides characteristics.

\begin{tabular}{|c|c|c|c|c|c|c|c|c|c|c|}
\hline \multirow{3}{*}{ Model } & \multirow{3}{*}{ Fixer } & \multirow{3}{*}{ Staining } & \multicolumn{7}{|c|}{ No. of samples for group } & \multirow{3}{*}{$\%$ counted samples } \\
\hline & & & \multicolumn{7}{|c|}{ Group } & \\
\hline & & & 1 & 2 & 3 & 4 & 5 & 6 & 7 & \\
\hline DAP 1 & Xylol & MG & 17 & 28 & 1 & 0 & 0 & 1 & 1 & 2,1 \\
\hline DAP2 & Xylol & BP & 11 & 16 & 0 & 21 & 0 & 0 & 0 & 0 \\
\hline DAP3 & Xylol & WR & 48 & 0 & 0 & 0 & 0 & 0 & 0 & 0 \\
\hline DAP4 & Xylol & $\mathrm{P}$ & 48 & 0 & 0 & 0 & 0 & 0 & 0 & 0 \\
\hline DAP5 & Carnoy & MG & 0 & 46 & 0 & 0 & 2 & 0 & 0 & 0 \\
\hline DAP6 & Carnoy & BP & 0 & 0 & 0 & 8 & 0 & 0 & 40 & 83,4 \\
\hline Total & & & 124 & 90 & 1 & 29 & 2 & 1 & 41 & 14,2 \\
\hline
\end{tabular}

PAD: model of combination fixative and staining; MG: May-Grünwald-Giemsa; BP: Broadhurst-Paley; WR: Wright; P: Panótico; group 1: blurry; group 2: dirty field; group 3: crackled; group 4: little stained; group 5: very stained; group 6: no fixation; group 7: counted. 

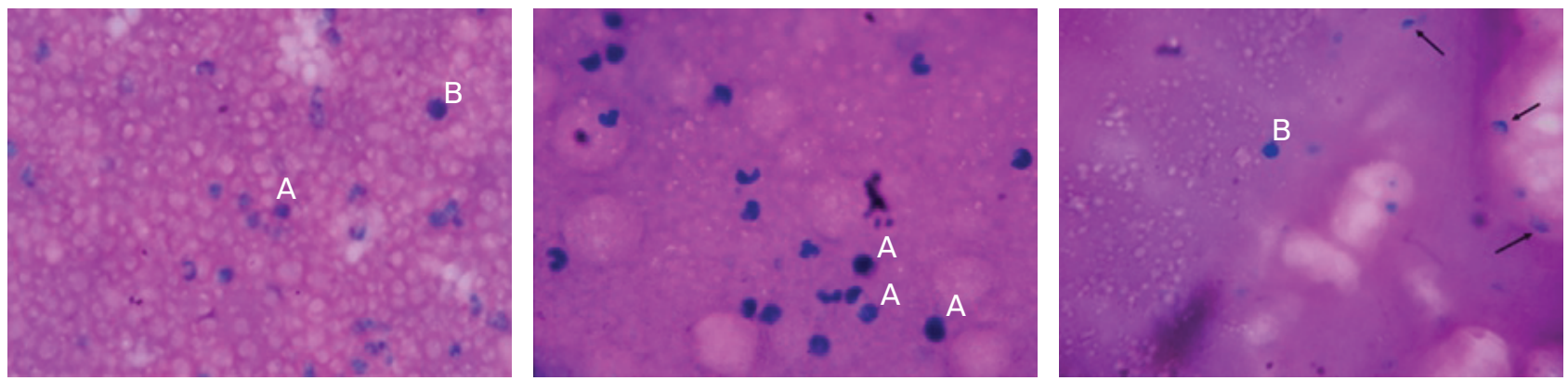

Figure 2. Smear of ovine milk for somatic cell counting prepared with Carnoy's solution and Broadhust-Paley staining, evidencing: (A) mononuclear cells; (B) polymorphonuclear; (arrows) corpuscles of inclusion (magnification $100 \times$ ).

distinction of cytoplasmic corpuscles (Fig. 2), avoiding that they could be mistakenly included in the cell count. Although VIANA et al. (2010), on the other hand, have observed changes in cell morphology in bovine milk with the Broadhurst-Paley staining.

SCC by direct microscopy in ovine milk is still little studied and needs greater attention, being an alternative for areas distant from the reference centers with specific equipment for implementation of automated SCC.

Based on the observed results, it was determined that the protocol using Carnoy's solution and Broadhurst-Paley staining was more effective for the removal of fat and the film adherence to milk glass slides. It had easy implementation, fewer steps and less time for performing the technique.

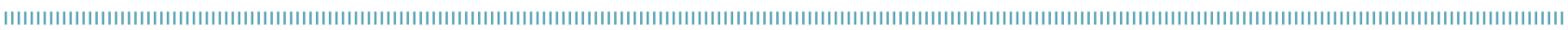
REFERENCES

ARCURI, E..; SILVA, P.D..; BRITO, J.R.F.; SILVA, M.R.; SOUZA, G.N. Emprego do Somacount 300, calibrado com leite de vaca, na contagem de células somáticas no leite de cabra. Ciência Rural, Santa Maria, v.34, n. 5, p.1497-1500, 2004.

BAGLITZ, M.G.; BATISTA, C.F.; SOUZA, F.N.; BENITES, N.R.; MELVILE, P.A.; STRICAGNOLO, C.R.; RICCIARDI, M., GOMES, V., AZEDO, M.R., SANCHES, B.G.S., DELLA LIBERA, A.M.M.P. Perfil celular e microbiológico do leite de ovelhas Santa Inês no período lactante e pós-desmame. Pesquisa Veterinária Brasileira, Rio de Janeiro, v.28, n.9, p.417-422, 2008.

BAGLITZ, M.G.; BENITES, N.R.; BATISTA, C.F.; SOUZA, F.N.; DIAS, R.A.; GOMES, V.; DELLA LIBERA, A.M.M.P. Variações metodológicas de células somáticas do leite de ovelha da raça Santa Inês. Ciência Rural, Santa Maria, v.43, n.4, p.668-671, 2013. http://dx.doi. org/10.1590/SO103-84782013000400016

GOMES, V.; AMATO, A.L.; PONTE, G.C.T..; BLAGITZ, M.; MADUREIRA, K.M.; DELLA LIBERA, A.M.M.P. Contagem automática e microscópica direta das células somáticas do leite de ovelhas da raça Lacaune, utilizando como corantes o Rosenfeld e verde de metil e pironina-y. Ciência Animal Brasileira, Goiãnia, v. 1 1, n. 1, p. 162-167, 2010. http://dx.doi.org/10.5216/cab.v1 1i1 1.4627

GOMES, V.; BAGLITZ, M.G.; MADUREIRA, K.M.; DELLA LIBERA, A.M.M.P. Avaliação da contagem de células somáticas (CCS) para diagnóstico de infecção mamária em ovelhas da raça Lacaune. Ensaios e Ciência, Campo Grande, v.12, p.163-170, 2008.

MADUREIRA, K.M.; GOMES, V.; DE CASTRO, R.S.; KITAMURA, S.S.; DE ARAÚJO, W.P. Análise das metodologias diretas e indiretas para a contagem de células somáticas no leite de cabras hígidas. Pesquisa Veterinária Brasileira, Brasília, v.30, n.4, p.311-316, 2010. http://dx.doi.org/10.1590/SO100-736X2010000400005
MENDONÇA, J.F.P.; SÁ, C.V.G.C.; CARVALHO, L.B.; MELO, C.B. Composição físico-química do leite de ovelhas e principais fatores que interferem na sua qualidade. Ciência Veterinária nos Trópicos, Recife, v.13, n.1/2/3, p.38-44, 2010.

PUCHTLER, H.; WALDROP, F.S.; CONNER, H.M.; TERRY, M. Carnoy fixation: practical and theoretical considerations. Histochemistry and Cell Biology, Berlin, v. 16, n.4, p.361-371, 1968.

SCHALM, O.W.; CARROL, E.J.; JAIN, N.C. Bovine mastitis. Philadelphia: Lea \& Febiger, 1971. 360p.

SOUZA, F.N.; BLAGITZ, M.G.; PENNA, C.F.A.M.; DELLA LIBERA, A.M.M.P.; HEINEMANN, M.B.; CERQUEIRA, M.M.O.P. Somatic cell count in small ruminants: Friend or foe? Small Ruminant Research, v. 107, n. 2-3, p.65-75, 2012.

STEHLING, R.N.; VARGAS, O.L.; SOUZA, H.M.; PORTUGAL, H.T.B. Relação entre a contagem microscópica direta e os testes "Califórnia Mastitis Test" e "Whiteside" na determinação de células somáticas em leite caprino. Revista do Instituto de Laticínio Cândido Tostes, Juiz de Fora, v.43, n.258, p.3-8, 1988.

SUMMER, A.; MALACARNE, M.; SANDRI, S.; FORMAGGIONI, P.; MARIANI, P. Effects of somatic cell count on the gross composition, protein fractions and mineral content of individual ewe's milk. African Journal of Biotechnology, Nairobi, v.1 1, n.97, p.16377-16381, 2012. http://dx.doi.org/10.4172/2155-9872.1000269

VIANA, K.F.; SETUBAL, B.F.; MENDES, V.A.; GRASSE, P.A.P.; ZANINI, M.S. Comparação da contagem de células somáticas em leite cru por quatro métodos de coloração. Acta Veterinaria Brasilica, Mossoró, v.4, n.1, p.59-63, 2010. 